\title{
PENGEMBANGAN WEB TPA MIFTAHUL JANNAH MENUJU TPA YANG MANDIRI DAN SEJAHTERA
}

\author{
${ }^{(1)}$ Hidayatulah Himawan, ${ }^{(2)}$ Dessyanto B.P. \\ ${ }^{(1,2)}$ Prodi. Teknik Informatika \\ Universitas Pembangunan Nasional "Veteran" Yogyakarta \\ Tambakbayan 2 Babarsari, Yogyakarta \\ email : if.iwan@upnyk.ac.id
}

\begin{abstract}
Abstrak
Growth and development of young children should be guided from the beginning . Education is carried out continuously should be directed to a positive destination. Garden Education Al - Quran (TPA) is one means of education that provides the fundamentals of the science of understanding the religion (Islam). Jannah is a landfill Miftahul education institutions, from time to time with the level of activity that the higher activity, requires a medium for the board to be able to provide opportunities for the students to improve the ability and quality of human resources, especially in the management of information systems towards a more independent and TPA prosperous, using IT as a tool to help increase performance. The process of quality improvement and the ability to lead an independent and prosperous landfill, by submitting any reports and conditions in the landfill Miftahul Jannah quickly and easily accessible by anyone. Report and the information addressed to the board and donors involved directly or indirectly. Conducted an online web system development to lay any existing reports. In addition, an increase in capacity through training to use online web administrators or managers of the system at the landfill Miftahul Jannah. This is done so that the ability of life skills can be used as a tool for the managers in the landfill Miftahul Jannah for entrepreneurship can be independently and enhance confidence .
\end{abstract}

Keywords : Taman Pendidikan Al-Qur'an, Web Online, Information System

Pertumbuhan dan perkembangan anak usia dini harus dibimbing sejak awal. Pendidikan yang dilaksanakan secara terus-menerus harus bisa diarahkan ke tujuan yang positive. Taman Pendidikan Al-Quran (TPA) merupakan salah satu sarana pendidikan yang memberikan dasar-dasar pemahaman dengan ilmu keagamaan (Islam). TPA Miftahul Jannah yang merupakan lembaga pendidkan, dari waktu ke waktu dengan tingkat aktifitas kegiatan yang semakin tinggi, memerlukan suatu media bagi pengurus untuk dapat memberikan peluang bagi para santri untuk meningkatkan kemampuan dan kualitas SDM khususnya pada pengelolaan sistem informasi menuju suatu TPA yang lebih mandiri dan sejahtera, dengan mempergunakan IT sebagai alat pembantu peningkatan kinerja. Proses peningkatan kualitas dan kemampuan untuk menuju TPA yang mandiri dan sejahtera, dilakukan dengan menyampaikan setiap laporan dan kondisi di TPA Miftahul Jannah secara cepat dan mudah dijangkau oleh siapapun. Laporan dan informasi tersebut ditujukan kepada para pengurus dan donatur yang terlibat secara langsung ataupun tidak langsung. Pengembangan sistem web online dilaksanakan untuk meletakkan setiap laporan yang ada. Selain itu, peningkatan kemampuan melalui pelatihan penggunaan web online kepada para administrator atau pengelola sistem di TPA Miftahul Jannah. Hal ini dilakukan agar kemampuan life skill dapat dijadikan alat bagi para pengelola di TPA Miftahul Jannah untuk dapat lebih berwirausaha secara mandiri dan meningkatkan kepercayaan diri.

Kata kunci : Taman Pendidikan Al-Quran (TPA), Web Online, Sistem Informasi

\section{PENDAHULUAN}

Teknologi yang terus berkembang saat ini membawa dampak positif dan negatif bagi seluruh kehidupan masyarakat. Jika bisa mengolah dan menggunakan teknologi tersebut dengan baik, maka akan didapatkan manfaat yang luar biasa, namun jika tidak tepat dalam pengolahan dan penggunaannya, maka akan lebih banyak kerugian dan "mudhorat" yang di dapat. Transparansi informasi baik yang positif maupun negative tidak bisa terbendung lagi, 
mau tidak mau kita harus menerima kedatangannya dimata kita, dalam menghadapi era globalisasi semacam ini tidak sedikit orang tua yang khawatir akan masa depan anaknya. Mereka sangat membutuhkan pendampingan pendidikan agama sejak dini, dengan harapan mereka bisa membedakan mana yang hak dan mana yang batil. Generasi muda yang bisa dibilang menjadi penerus bangsa, memiliki tanggung jawab untuk dapat membangun negara dan bangsa dengan dilandaskan oleh nilai-nilai keagamaan. Untuk itulah pada tanggal 11 Oktober 2009 berdiri Taman Pendidikan Al Qur'an (TPA) Miftahul Jannah yang merupakan salah satu tempat yang diharapkan bisa membina dan membangun generasi bangsa yang berkualitas serta Bertaqwa kepada Tuhan Yang Maha Esa.

TPA Miftahul Jannah yang pada awalnya dipelopori oleh Takmir Masjid Miftahul Falaah dan muda-mudi Sonosori, mulai berkembang dengan diikuti oleh santri-santri yang terdiri dari beberapa kelompok. Untuk membina dan melatih anak-anak santri, TPA Miftahul Jannah membagi menjadi 4 (empat) kelompok santri, yang terdiri dari Kelas A untuk usia Pra-TK dan TK (Taman Kanan-Kanak), Kelas B untuk anak-anak yang duduk di kelas 1 s.d 3 SD (Sekolah Dasar), Kelas $C$ untuk anak-anak yang duduk di kelas 4 s.d 6 SD, serta Kelas D untuk anakanak yang duduk di SMP /MTS atau TPA Lanjutan. Perbandingan antara santri dan jumlah pengajar (Astadz) di setiap kelasnya disesuaikan dengan kebutuhan yang ada. Di Kelas A yang diikuti oleh 12 anak didik diasuh oleh 2 orang Astadz, Kelas B yang diikuti oleh 13 anak didik diasuh oleh 3 orang Astadz, Kelas $C$ yang diikuti oleh 10 anak didik diasuk oleh 3 orang Astadz dan Kelas D yang diikuti oleh 12 anak didik di asuh oleh 3 orang Astadz. Selain itu, TPA Miftahul Jannah juga memiliki 8 (delapan) orang Ustad Tetap dan 3 (tiga) orang Ustad Tidak Tetap.

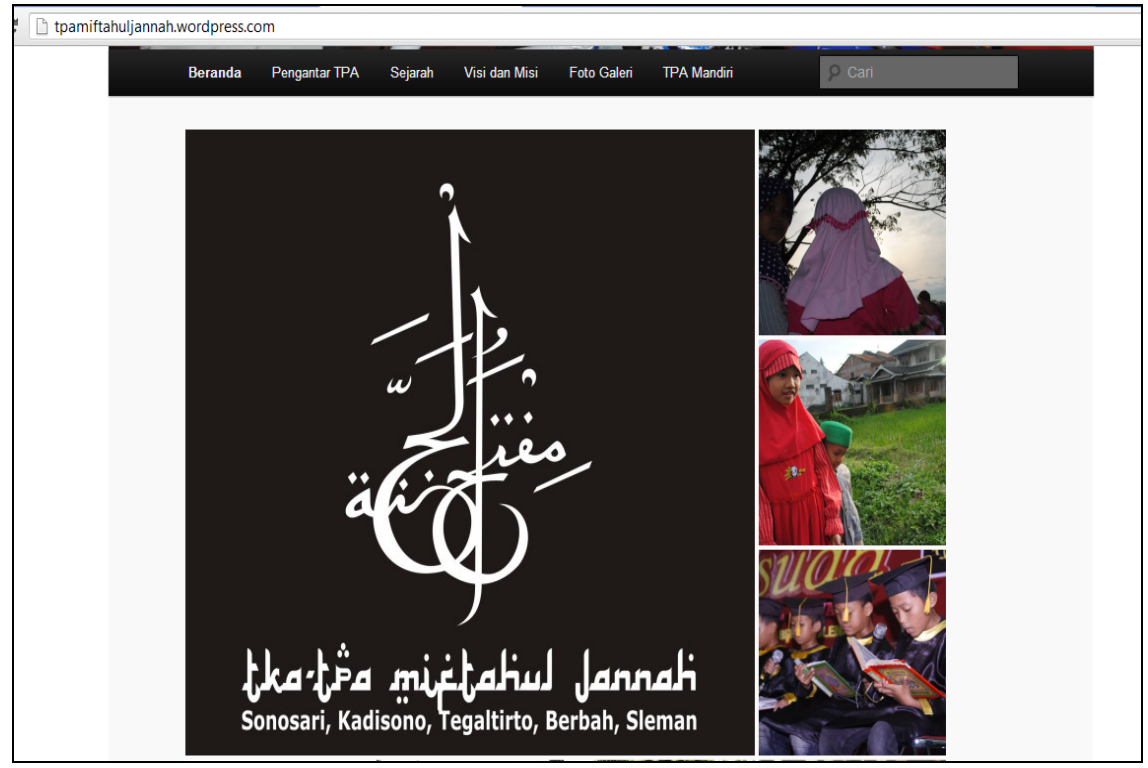

Gambar 1. Web online TPA Miftahul Jannah

Perkembangan TPA Miftahul Jannah dari waktu ke waktu dengan tingkat aktifitas kegiatan yang semakin tinggi, memerlukan suatu media bagi pengurus untuk dapat memberikan peluang bagi para santri untuk meningkatkan kemampuan dan kualitas SDM khususnya pada pengelolaan sistem menuju suatu TPA yang lebih mandiri dan sejahtera, dengan mempergunakan IT sebagai alat pembantu peningkatan kinerja.

Proses peningkatan kualitas dan kemampuan untuk menuju TPA yang mandiri dan sejahtera, mulai dilakukan dengan menyampaikan setiap laporan dan kondisi di TPA Miftahul Jannah secara cepat dan mudah dijangkau oleh siapapun. Laporan dan informasi tersebut ditujukan kepada para pengurus dan donatur yang terlibat secara langsung ataupun tidak langsung. Sebagai permulaan, kami telah memberikan pengembangan sistem blog dan web online untuk meletakkan setiap laporan yang ada. Selain itu, juga mengadakan pelatihan penggunaan blog atau web online kepada para administrator atau pengelola sistem di TPA Miftahul Jannah. Hal ini dilakukan agar kemampuan life skill dapat dijadikan alat bagi para pengelola di TPA Miftahul Jannah untuk dapat lebih berwirausaha secara mandiri dan 
meningkatkan kepercayaan diri mereka sebagai bagian dari pengguna sistem yang tidak bisa dipandang sebelah mata.

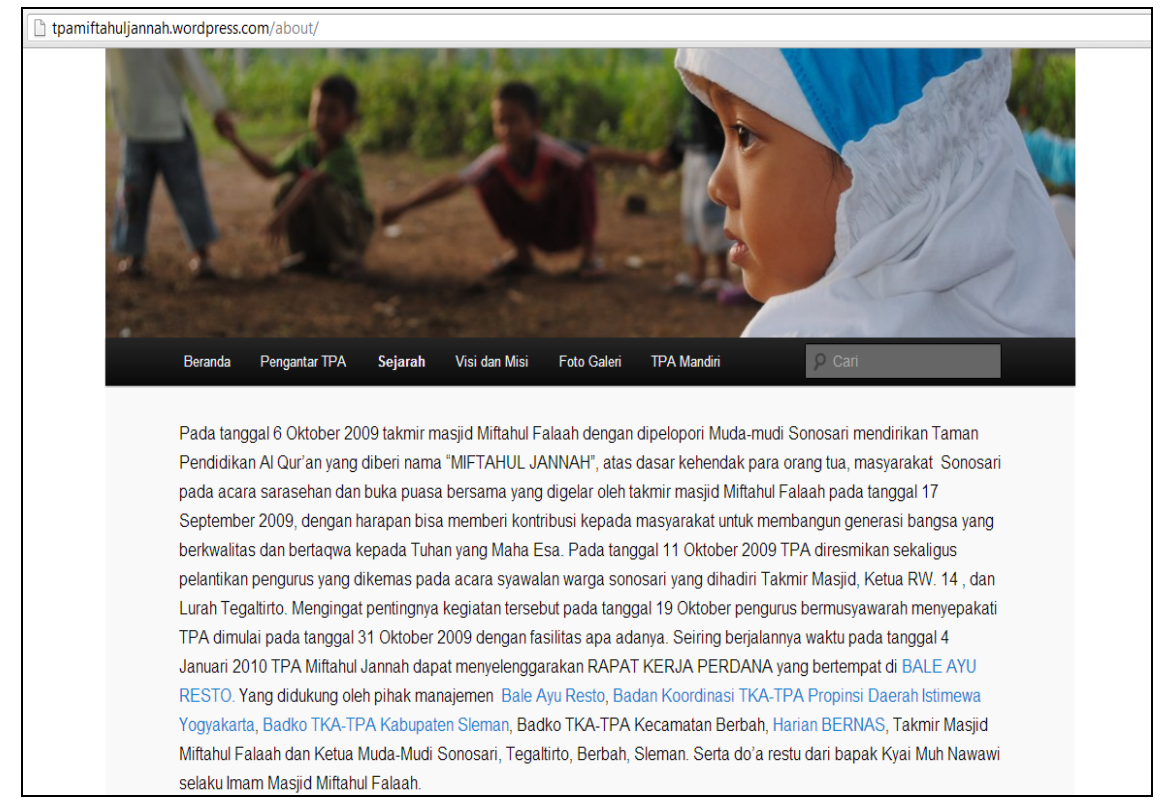

Gambar 2. Pengantar Web

TPA miftahul Jannah memiliki lokasi di kecamatan Sleman, dengan jarak sekitar $15 \mathrm{~km}$ dari program Studi Teknik Informati UPN "Veteran" Yogyakarta. Sarana transportasi yang bisa digunakan untuk menuju lokasi adalah kendaraan bermotor berupa angkutan umum bis dan motor.

Secara umum, lokasi yang agak terpisah dari jalan raya, membuat TPA miftahul jannah harus dapat lebih mandiri untuk berkomunikasi dan berinteraksi dengan dunia luar. Oleh karena itu, komunikasi yang dilakukan pada saat ini, lebih banyak menggunakan jaringan internet.

\section{Permasalahan}

Dari uraian di atas, maka di dapat 2 (dua) permasalahan utama yang dihadap oleh TPA Miftahul Jannah, yaitu :

a. Bagaimana meningkatkan kemampuan SDM yang dimiliki oleh TPA, untuk mengelola dan membangun sebuah web online yang dapat memberikan informasi dan pelaporan secara langsung kepada para masyarakat.

b. Bagaimana meningkatkan kualitas pengelolaan Miftahul Jannah untuk menjadi sebuah TPA yang lebih mandiri dan sejahtera dengan kemampuan dan fasilitas yang dimiliki.

Kedua permasalahan tersebut harus dapat dikelola dan dikendalikan secara langsung, agar proses peningkatan kemampuan pengelolaan untuk menuju sebuah TPA yang lebih mandiri dan sejahtera dapat terlaksana dengan baik dan tepat sasaran.

\section{TINJAUAN PUSTAKA}

\section{Pengertian Internet}

Internet adalah singkatan dari Interconnection Network yang secara harfiah berarti hubungan antar jaringan komputer (network). Sedangkan network sendiri diartikan sebagai suatu sistem komunikasi data antar komputer. Contoh jaringan komputer yang paling sering kita temukan misalnya LAN (Local Area Network) yang menghubungkan komputer-komputer yang berada dalam suatu areal atau lokasi tertentu seperti kantor, sekolah, perusahaan, warnet, dan lain-lain.

Gambaran sederhananya seperti ini: beberapa komputer dihubungkan satu sama lain sehingga membentuk jaringan komputer (network). Bila sejumlah network (jaringan komputer) kemudian digabung dan dihubung-hubungkan lagi maka jadilah internet. 
Jadi pengertian internet secara umum (menurut bahasa) adalah kumpulan dari jaringan komputer yang terhubung dan bekerja sebagai suatu sistem. Sedangkan pengertian Internet secara khusus (inilah yang sering terpakai dan yang dimaksud dalam pembahasan ini) adalah suatu jaringan komputer terbesar di dunia karena menghubungkan seluruh jaringan komputer yang ada di dunia ini. Untuk ringkasnya, Internet adalah jaringan komputer global sedangkan jaringan komputer lokal (LAN) dinamakan Intranet.

Untuk mendapatkan akses internet, sebuah komputer harus menggunakan jasa perusahaan penyedia layanan internet atau Internet Service Provider (ISP). Dengan jasa perusahaan ISP ini, kita bisa mendapatkan jalur internet (online) setelah menghubungkan komputer kita dengan komputer servernya. Hubungan (koneksi) antara komputer pengguna dengan komputer server perusahaan ISP tersebut biasanya dilakukan lewat jaringan telepon (dial-up) dengan menggunakan peralatan modem. Lewat komputer server yang dimiliki oleh ISP itulah kita bisa terhubung dengan jaringan komputer sedunia (internet).

\section{Metode Pengembangan Sistem Pakar}

Metode pengembangan sistem yang digunakan dalam penelitian ini menggunakan metode pengembangan sistem pakar. Terdapat enam tahap atau fase dalam pengembangan sistem pakar. Penjelasan berikut merupakan penjelasan secara garis besar tentang fase-fase pengembangan tersebut.

1. Penilaian keadaan

Tahap ini merupakan tahap penentuan hal-hal penting sebagai dasar dari permasalahan yang akan dianalisis. Tahap ini merupakan tahap untuk mengkaji dan membatasi masalah yang akan diimplementasikan dalam sistem. Setiap masalah yang diidentifikasi harus dicari solusi, fasilitas yang akan dikembangkan, penentuan jenis bahasa pemrograman dan tujuan yang ingin dicapai dari sistem tersebut.

\section{Koleksi pengetahuan}

Hasil identifikasi masalah dikonseptualisasi dalam bentuk relasi antar data, hubungan antar pengetahuan dan konsep-konsep penting dan ideal yang akan diterapan dalam sistem. Pada tahap ini juga menganalisis data-data penting yang harus didalami bersama dengan pakar dibidang permasalahan tersebut, hal ini dilakukan untuk memperoleh informasi hasil wawancara dan observasi sehingga dapat memberikan jawaban pasti bahwa sasaran permasalahan tepat, benar dan sudah selesai.

\section{Perancangan}

Pada tahap ketiga ini, data-data yang terdapat pada tahap kedua diimplementasikan secara formal, misalnya memberikan kategori sistem yang akan dibangun, mempertimbangkan beberapa faktor pengambilan keputusan seperti keahlian manusia, tingkat kesulitan yang mungkin terjadi, dokumentasi kerja dansebagainya. Pada tahap ini juga prototype sistem sudah mulai dibangun. Tahap ini diakhiri dengan penyelesaian desain.

\section{Tes}

Pada tahap ini sistem telah selesai dibangun dan harus dilakukan evaluasi untuk menguji dan menemukan kesalahannya. Hal ini merupakan hal yang umum dilakukan karena suatu sistem belum tentu sempurna setelah selesai pembuatannya sehingga proses evaluasi diperlukan untuk penyempurnaanya. Dalam evaluasi akan ditemukan bagian-bagian yang harus dikoreksi untuk menyamakan permasalahan dan tujuan akhir pembuatan sistem. Sistem yang telah diinstal di demonstrasikan dan langsung diuji untuk menyelesaikan suatu kasus.

\section{Dokumentasi}

Dalam tahap ini tes-tes yang telah dilakukan di dokumentasikan agar dapat diperoleh sistem yang baik dan memenuhi standarisasi.

\section{Pemeliharaan}

Tahap ini menjelaskan tentang hal-hal yang dilakukan setelah sistem diaplikasikan kedunia nyata yaitu bagaimana memelihara, mengembangkan dan melakukan evaluasi sistem secara periodik. Pengembangan sistem diperlukan agar sistem yang akan dibangun tidak menjadi using dan investasi sistem tidak sia-sia. Hal pengembangkan sistem yang paling 
berguna adalah proses dokumentasi sistem dimana didalamnya terdapat semua hal penting yang dapat menjadi tolak ukur pengembangan sistem dimasa mendatang termasuk didalamnya adalah basis pengetahuan masalah yang diselesaikan. Fase pengembangan sistem pakar dapat dilihat pada gambar 2.8 (Kusumadewi,2003):

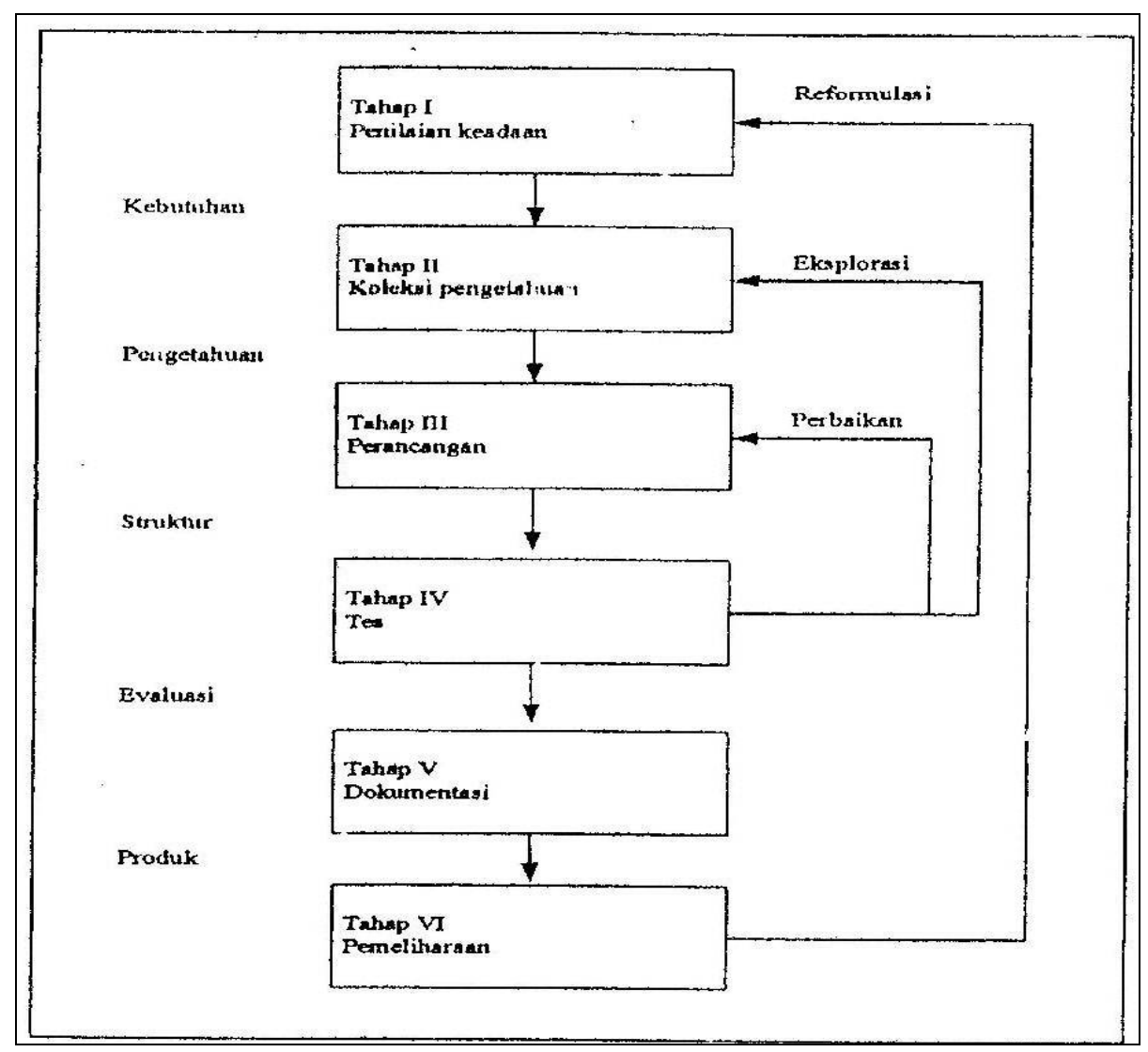

Gambar 3. Fase Pengembangan Sistem Pakar

\section{Solusi yang Ditawarkan}

Dari 2 (dua) permasalahan yang ada, setiap permasalahan memiliki sasaran yang berbeda. Tiap permasalahan memiliki cara dan kondisi tertentu yang dapat dilakukan untuk menghasilkan sebuah keputusan dan hasil sesuai dengan yang diharapkan. Proses pencarian solusi terhadap permasalahan yang ada, dilakukan dengan metode pendekatan dan diskusi terhadap keinginan dari pelaksana dan koordinator TPA Miftahul Jannah. Metode pendekatan yang dilakukan lebih kepada untuk melihat situasi dan kondisi yang sebenarnya. Pendekatan ini lebih mengarah kepada proses diskusi yang dilaksanakan secara nyata dan berkelanjutan, dan diharapkan dapat mensinergikan kegiatan-kegiatan yang selama ini telah dilaksanakan untuk dapat dituangkan ke dalam sebuah sistem yang lebih terpadu.

\section{Metode yang Digunakan}

Kegiatan dilakukan dengan menggunaan metode yang meliputi :

1. Penyuluhan manfaat komputer untuk mempermudah dan mempercepat pekerjaan. Tahap demi tahap dijelaskan dibarengi dengan tanya jawab untuk mengobati rasa penasaran masyarakat khususnya guru dan siswa tentang fungsi komputer

2. Pelatihan Komputer dengan cara praktek langsung yang sebelumnya dijelaskan tentang perintah-perintah yang digunakan.

3. Praktek langsung meliputi materi cara menghidupkan komputer, menjalankan sistem operasi windows dan menjalankan aplikasi e-mail (mail.yahoo.com) dan blog (wordpress)

4. Contoh-contoh praktis yang mudah dipahami dan diikuti oleh para peserta pelatihan. 


\section{Target Luaran}

Dari kegiatan yang akan dilaksanakan, maka penerapan sistem online ini diharapkan berupa :

a. Perubahan pengelolaan sistem pelaporan agar menjadi lebih baik

b. Peningkatan partisipasi masyarakat terhadap pengelolaan TPA dapat tercapai

c. Sistem pelaporan dan penyampaian informasi kepada masyarakat dapat terlaksana untuk menyampaikan pertanggungawaban penggunaan dana ataupun kegiatan yang dilaksanakan

\section{Pelaksanaan}

Dengan metode pendekatan dan diskusi yang telah dilakukan, maka secara rinci terdapat beberapa langkah penyelesaian terhadap permasalahan yang ada, dengan dituangkan ke dalam bentuk kegiatan yang lebih nyata. Adapun bentuk dan langkah kegiatan tersebut adalah sebagi berikut :

1. Permasalahan dalam peningkatkan kemampuan SDM yang dimiliki oleh TPA, terutama untuk mengelola dan membangun sebuah web online yang dapat memberikan informasi dan pelaporan secara langsung kepada para masyarakat. Bentuk kegiatan dan langkah penyelesaian yang lebih konkret dilakukan dengan cara :

a. Pelatihan tenaga administrasi sistem dalam pengelolaan sistem online. Pada pelatihan ini, tenaga atau SDM yang dimiliki oleh TPA Miftahul Jannah akan diberikan suatu proses dan metode pelatihan langsung, untuk mengembangkan sebuah sistem yang telah dimiliki. Proses pelatihan ini akan dilakukan bekerja sama dengan Laboratorium Jaringan yang dimiliki oleh Program Studi Teknik Informatika, sehingga para tenaga atau SDM yang akan dilatih, akan langsung berhadapan dengan permasalahan yang ada. Solusi dan pemecahan permasalahan yang ada, akan dilakukan secara bertahap sesuai dengan kemampuan dan kualitas SDM, hingga target penyampaian materi pelatihan akan dapat tercapai sesuai dengan tahapan dan langkah-langkah yang telah direncanakan.

b. Pembangunan web online. Proses pembangunan web online yang dimiliki oleh TPA Miftahul Jannah, selama ini telah dikelola oleh tenaga dan SDM yang terbatas. Dengan fasilitas yang kurang mendukung, maka pengelolaan web yang dilakukan tidak bisa dilaksanakan secara langsung. Oleh karena itu, tim melakukan pengembangan terhadap web yang dimiliki. Fasilitas pendukung web akan dikembangkan sesuai dengan kebutuhan dari TPA itu sendiri. Tim pelaksana akan memberikan sebuah fasilitas pengembangan web kepada pengelola sistem TPA menggunakan sistem online (www.miftahuljannah.info). Wordpress adalah sebuah sistem pengembangan web online yang memiliki template atau themes tersendiri sesuai dengan kebutuhan pengguna. Wordpress memiliki 2 (dua) model yang berbeda, yaitu model yang menggunakan fasilitas free dan model yang menggunakan fasilitas ber-bayar. Tenaga pengelola TPA akan memberikan informasi dan data yang dibutuhkan oleh tim, untuk pengembangan web yang ada. Data dan informasi ini akan dikelola secara bersama oleh SDM yang dimiliki oleh TPA, sehingga sinergi dan kerja sama yang terbentuk anatar pengembang sistem dan tenaga SDM yang dimiliki oleh TPA akan semakin baik. 


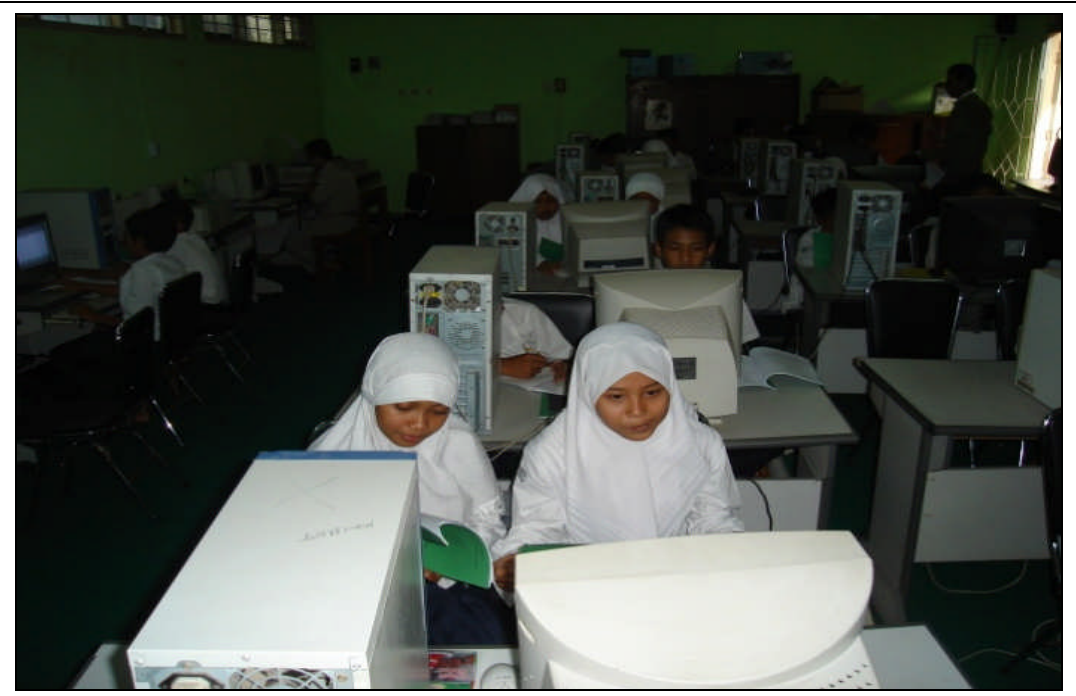

Gambar 4. Salah satu model pelatihan langsung

2. Permasalahan dalam meningkatkan kualitas pengelolaan Miftahul Jannah untuk menjadi sebuah TPA yang lebih mandiri dan sejahtera dengan kemampuan dan fasilitas yang dimiliki. Bentuk kegiatan dan langkah penyelesaian yang lebih konkret dilakukan dengan cara :

a. Mengelola setiap kegiatan pendidikan yang dilaksanakan oleh TPA menjadi lebih terpusat dan terpadu. Hal ini dilakukan agar tidak terjadinya kesalahan pengelolaan terhadap kegiatan yang dilakukan, mengingat jumlah santri dan tingkatan kelas yang sangat banyak, sehingga perlu pengelolaan penjadwalan dan SDM yang bertanggung jawab dalam kegiatan tersebut. Pengelolaan kegiatan ini dapat dilaporkan dan diinformasikan kepada pengelola sistem, untuk diletakkan sebagai agenda kerja yang lebih terjadwal. TPA sebagai penanggung jawab utama, dapat mengawasi setiap pelaksanaan kegiatan dengan tepat dan benar.

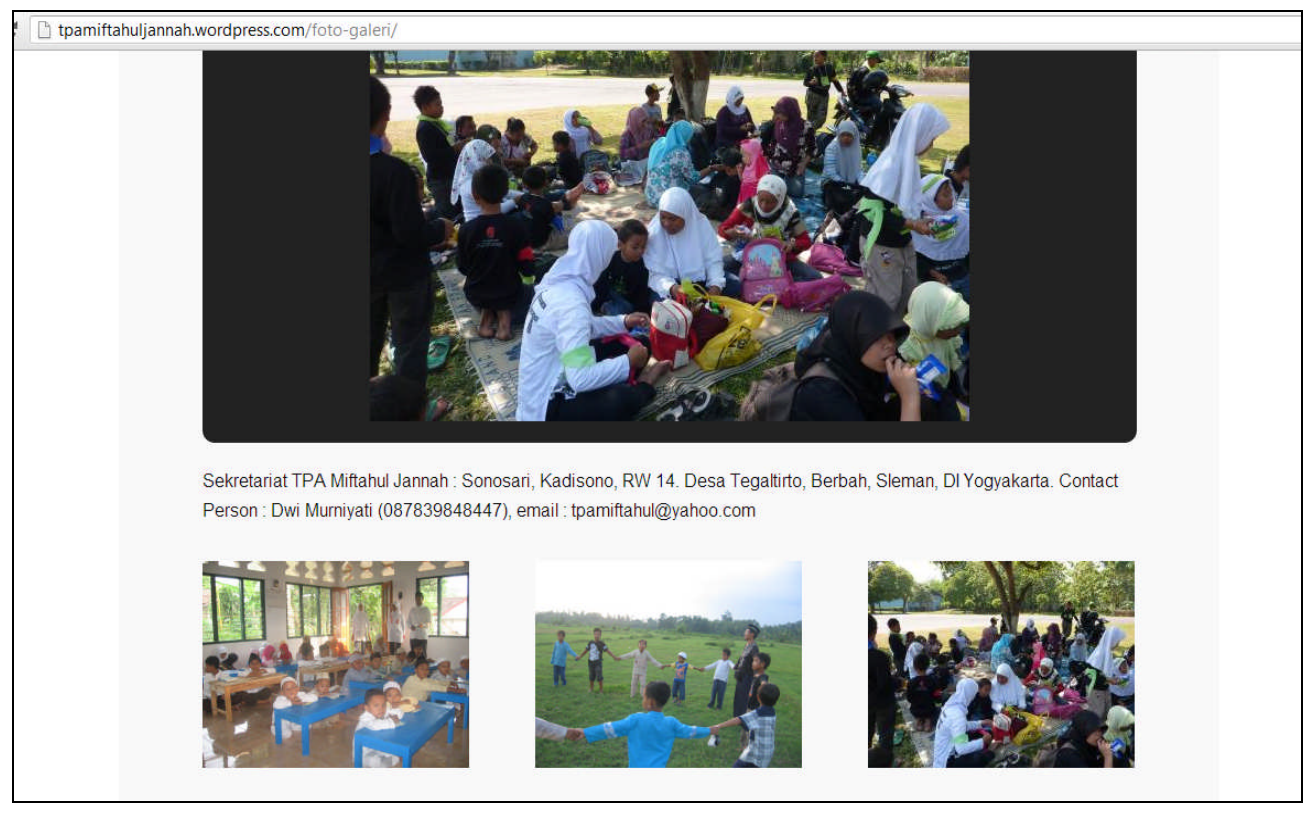

Gambar 5. Aktifitas Peserta Didik / Santri TPA Miftahul Jannah

Meningkatkan kemampuan wirausaha bagi para tenaga SDM di TPA Miftahul Jannah agar lebih mampu mandiri sesuai dengan kemampuan yang dimiliki. Kemampuan wirausaha ini dilakukan mengingat TPA Miftahul Jannah telah memiliki suatu program nyata dengan memanfaatkan 
berbagai barang yang tidak terpakai menjadi barang yang bermanfaat. Namun proses pengelolaan ini masih dilakukan secara sederhana dengan jangkauan wilayah yang terbatas. Untuk itu, tim pelaksana menggunakan sistem dan metode online untuk mengenalkan berbagai macam produk hasil kerajinan dan produk bumi lainnya, untuk dipasarkan secara langsung menggunakan fasilitas internet yang ada. Hal ini dilakukan agar produk yang dihasilkan dapat lebih dikenal oleh masyarakat luas, dan secara tidak langsung akan membantu proses pemasaran agar menghasilkan pendapatan yang lebih baik, dan dari pendapatan yang ada, akan digunakan untuk lebih meningkatkan kemampuan TPA Miftahul Jannah agar lebih mandiri dan sejahtera.

\section{IMPLEMENTASI}

1. Pelatihan tenaga administrasi

a. Pengelolaan sistem basis data MySql yang langusng

b. Pengelolaan data administrasi berbasis Microsoft Excel terhadap data SDM, data pelatihan, data donatur dan data kegiatan

c. Mengelola sistem jaringan koneksi internet menggunakan jaringan online

2. Pengembangan web online

Mengembangkan web online untuk menyampaikan informasi terhadap berbagai kegiatan yang dilaksanakan oleh TPA Miftahul Jannah.

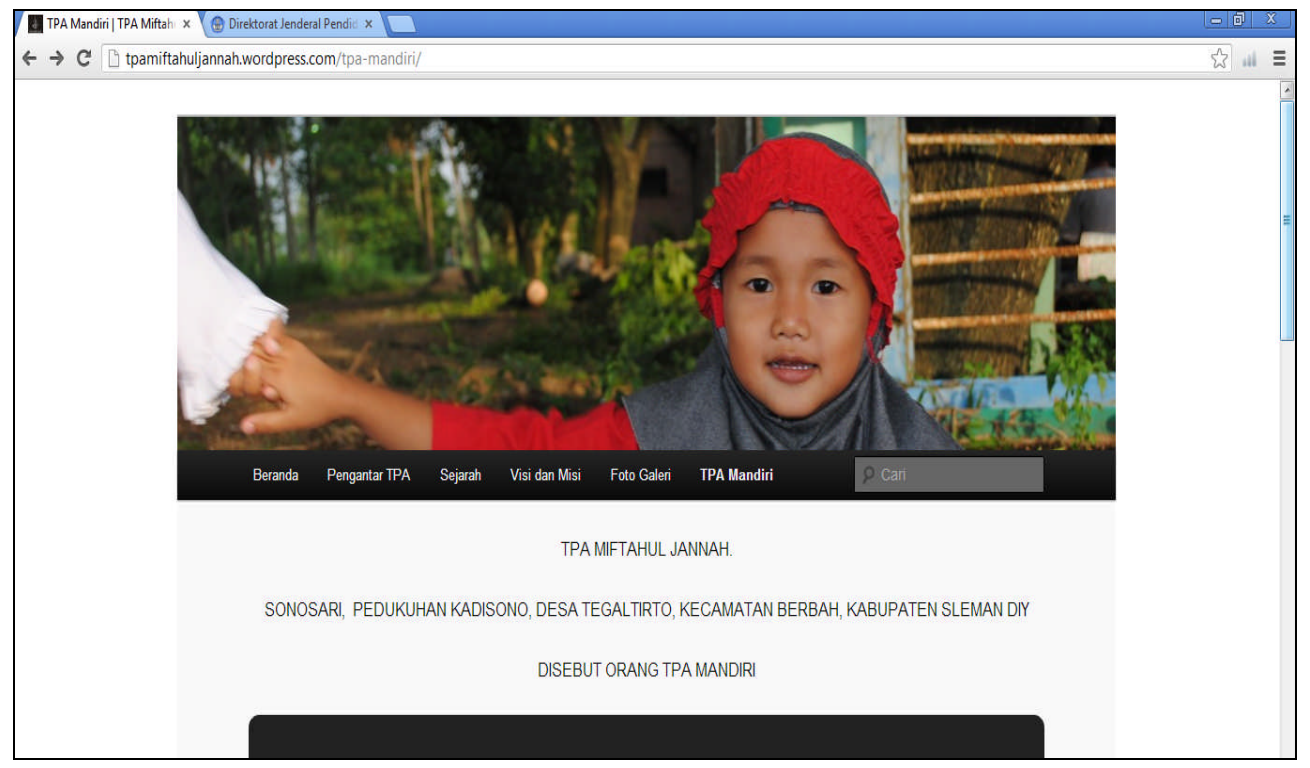

Gambar 6. Tampilan Halaman Web Utama

3. Pengelolaan dan penjadwalan kegiatan

a. Melakukan pengaturan jadwal pendidikan bagi peserta didik menggunakan sistem penjadwalan yang ada, khususnya dengan sistem informasi yang dibangun.

b. Melakuka pengaturan jadwal ekstrakurikuler sesuai dengan kemampuan dan tingkatan peserta didik.

4. Kemampuan wirausaha

a. Melakukan pengenalan kegiatan kemandirian kepada peserta didik dengan menghasilkan produk yang bernilai dan bermanfaat, terutama untuk produk kerajinan bambu dan produk rumah tangga.

b. Melakukan pengelolaan sistem penjualan online (online marketing atau ecommerce)

c. Melakukan promosi agar dapat meningkatkan jumlah pemasaran dengan mengenalkan produk ke berbagai instansi ataupun lembaga yang ada. 


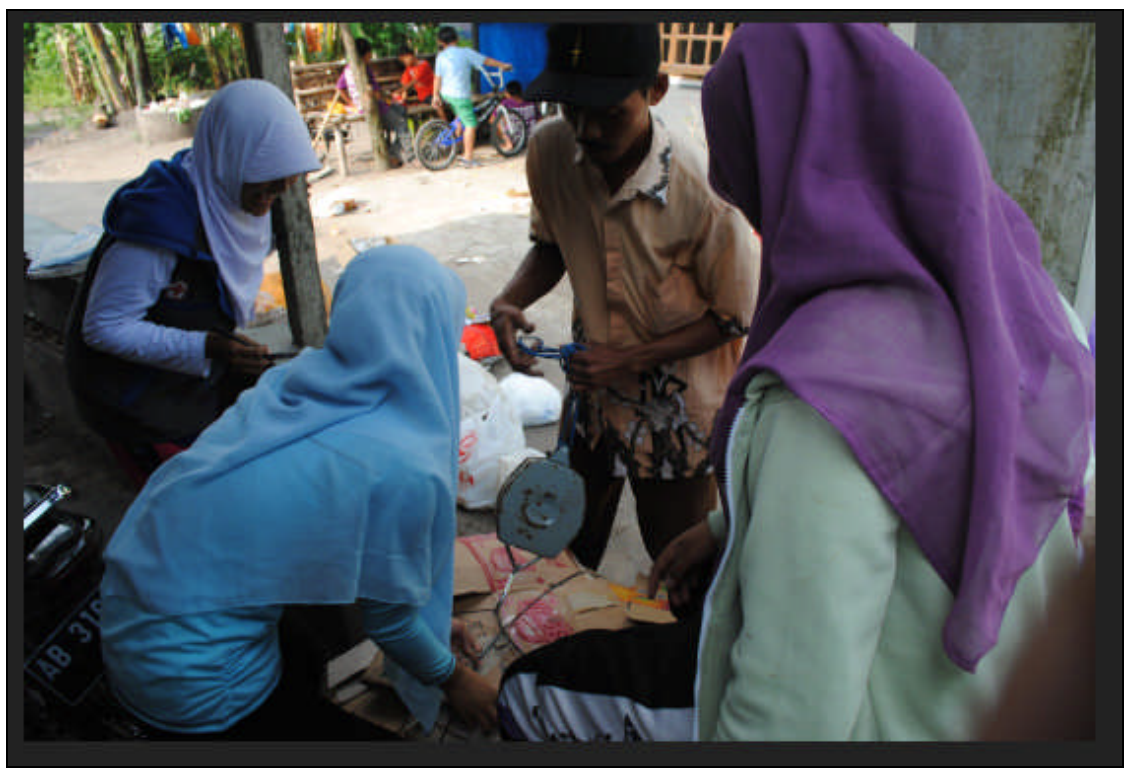

Gambar 7. Aktifitas Warga dalam Pengumpulan Dana

\section{KESIMPULAN}

Dari hasil pengembangan sistem web online ini, maka dapat ditarik beberapa kesimpulan diantaranya adalah :

1. Telah dihasilkan sebuah web online yang dapat membantu peningkatan kemampuan dari pengurus TPA untuk menjangkau para donatur dengan wilayah yang lebih luas.

2. Penyampaian informasi kepada para donatur dapat dilakukan secara online

3. Kegiatan lanjutan dapat dilakukan dengan memberikan penyuluhan tentang manfaat internet dan pengembangan blog secara mendalam dengan penguasaan terhadap kemampuan pengembangan perangkat lunak, agar dapat meningkatkan mutu dan kemampuan adminsitrator serta menjadi bekal untuk terjun langsung ke dunia kerja nantinya.

4. Sistem pelatihan dengan cara praktek langsung akan mempermudah pemahaman khususnya bidang computer, namun dperlukan adanya perangkat pendukung yang lebih memadai sesuai dengan kebutuhan yang ada

5. Penyuluhan dan pelatihan komputer hendaknya melihat sejauh mana kemampuan suatu kelompok dari segi sarana dan prasarana. 


\section{DAFTAR PUSTAKA}

Fathansyah, 2002, Basis Data, Informatika Bandung, Bandung.

Jogiyanto, 2001, Pengenalan Komputer, Andi Offset, Yogyakarta,

Kusumadewi, 2003, Artificial intelligence (Teknik dan Aplikasinya), Yogyakarta

Kuswarini $\mathrm{H}$, internet dan Pengenalan Blog, Uiversitas Negeri Yogyakarta, Yogyakarta.

Sutarman, 2003, Membangun Aplikasi Web dengan PHP dan MySQL, Andi Offset, Yogyakarta

Widjijono, 1995, Desaku dan Kampus Biru, Edisi ke-5, P3KKN LPM UGM, Yogyakarta

http://www.nurahratu.com/tutorial/web-design/1-latest-news/203-php-adalah.html) 